\title{
Approaches to Women and Development in Rural China
}

\author{
TAMARA JACKA*
}

In this paper I analyze the language and concepts framing approaches taken by the Chinese women's movement to women and rural development. Until the late 1990s the language adopted by Chinese women's organizations concerned with rural development was quite different from that of development agencies elsewhere, but since that time it has become increasingly similar. In this paper I ask: to what extent did the earlier language of Chinese women's development activists point to understandings and practices that were different from those of the global development movement? And what might be the significance of the growing convergence between the two?

\section{Introduction}

In this paper I analyze the language and concepts framing approaches taken by the Chinese women's movement to women and rural development. Until the late 1990s the language adopted by Chinese women's organizations concerned with rural development was quite different from that of development agencies elsewhere, but since that time it has become increasingly similar. In this paper I ask: to what extent did the earlier language of Chinese women's development activists point to understandings and practices that were different from those of the global development movement? And what might be the significance of the growing convergence between the two? ${ }^{1}$

\section{'Raising women's quality'}

In contemporary China, efforts aimed at improving the lives of rural women and at furthering their role in development are dominated by three sets of players: the

\footnotetext{
* Tamara Jacka is a senior fellow in the Gender Relations Centre, Research School of Pacific and Asian Studies, the Australian National University. Her research interests are in gender relations, social change and the situation of women in contemporary China. Her publications include Women's Work in Rural China. Change and Continuity in an Era of Reform (Cambridge University Press, 1997); On the Move: Women and Rural-to-Urban Migration in Contemporary China (co-edited with Arianne Gaetano, Columbia University Press, 2004); and Rural Women in Urban China: Gender, Migration, and Social Change (M. E. Sharpe, 2006). An earlier version of this paper was presented at the Symposium on Women's Participation in Policy Implementation and Institutional Change in Rural China, held in April 2004 at the University of Nottingham. The author is grateful to the organizer of the Symposium, Dr Sally Sargeson, and other participants, for their valuable comments.

1. My discussion is based on interviews with members of the All China Women's Federation (ACWF) at county, provincial and national level conducted in Sichuan, Shandong, Hangzhou, and Beijing in 1989, 1995 and 2001; seven months ethnographic fieldwork with the Cultural Development Center for Rural Women in Beijing in 2001 and 2002 ; and documentary research in English and Chinese.
} 
All China Women's Federation (ACWF), a 'mass organization' funded and closely supervised by the state, with representation at all levels of government; other Chinese women's non-governmental organizations (NGOs), most of which were established in the few years leading up to the Fourth World Conference on Women, held in Beijing in $1995 ;{ }^{2}$ and overseas donor agencies. The links and overlaps between these three are very strong. For example, most of the projects run by either overseas agencies or domestic NGOs involve grass roots Women's Federations as local partners. Furthermore, most NGOs that work with rural women emerged out of, rather than in opposition to, the ACWF, but they also owe their existence to foreign donors, especially the Ford Foundation, which funded the establishment of a number of women's groups and projects in the 1990s and which continues to be the major sponsor for the majority of Chinese women's NGOs. ${ }^{3}$

One of the oldest and most influential Chinese women's NGOs-the Rural Women collective-provides a good example of these links. The Rural Women journal, formerly Rural Women Knowing All (Nongjianü Baishitong), is China's only national periodical dedicated specifically to rural women, but its staff have also been involved in a number of rural development projects. These include a club for rural migrant women in Beijing, a Rural Women's Technical School on the outskirts of Beijing and a variety of village-level projects across the country. Rural Women was founded in 1993 by Xie Lihua, a member of the ACWF and deputy editor of the ACWF's daily newspaper, China Women's News. While most of the funding for the Rural Women collective comes from overseas development agencies, including The Global Fund for Women, The Asia Foundation, and Oxfam Hong Kong, as well as its major sponsor, the Ford Foundation, during the 1990s the collective came under the direct authority of China Women's News and the ACWF. In 2001, however, the collective underwent major restructuring with advice from an external consultant, a former employee of Oxfam Hong Kong. The Rural Women journal remained under the auspices of China Women's News but the collective's development projects were grouped under a new, independent non-governmental organization, the Cultural Development Center for Rural Women. Funding for this Center and for the development projects it runs comes primarily from global development agencies, and the Center is therefore under pressure to conform to the global agencies' priorities. At the same time, its village-level projects are established in response to requests made by local level Women's Federations and are run in partnership with them. ${ }^{4}$

2. The term 'non-governmental organization' (feizhengfu zuzhi) was not widely used in China until the Fourth World Conference on Women was held in Beijing in 1995. In the lead up to the Conference and its associated NGO Forum the ACWF began to call itself an NGO and to participate in international NGO activities. However, most people continued to regard the ACWF as an official organization. Meanwhile, between 1992, when it was announced that the Fourth World Conference on Women would be convened in Beijing, and the Conference itself, greater international contacts, provided by the preparatory meetings for the Conference and its NGO forum, inspired Chinese women to set up new, self-described NGOs separate from the ACWF. China's hosting of the Fourth World Conference on Women and its NGO Forum lent legitimacy to these groups, and international donors, especially the Ford Foundation, provided them with funding. See Sharon Wesoky, Chinese Feminism Faces Globalization (New York and London: Routledge, 2002), pp. 113-184.

3. Ibid., pp. 161-162, 239, 244-245.

4. For further examples of the links between the ACWF, Chinese women's NGOs, and overseas development agencies, see Ping-Chun Hsiung et al., eds, Chinese Women Organizing. Cadres, Feminists, Muslims, Queers (Oxford and New York: Berg, 2001). 
In addition to overlaps in structures and personnel, the values, goals and strategies of Chinese women's NGOs and of the ACWF have also been quite similar. In the early 1980s the ACWF focused its energy on improving family life, promoting legal education amongst rural women and on combating violence against women. ${ }^{5}$ Since the mid-1980s, however, the overwhelming focus of ACWF work in rural areas has been the alleviation of poverty and the strengthening of women's ability to compete in the market economy. This is reflected in its nationwide campaign to 'study culture, study technology; compete in results, compete in contributions' or 'double study, double compete' (shuang xue shuang bi) campaign for short. The aim of the campaign, which the ACWF runs in conjunction with a number of government ministries, has been to encourage and help women to improve their skills and productivity in commercial agricultural production, although in recent years there has also been encouragement for household-based enterprises in commerce and services, and craft production for export. ${ }^{6}$ Leaders of the ACWF have explained the focus on agriculture as both a reflection of the state's emphasis on the fundamental importance of agriculture to the national economy and of the fact that women have increasingly become the major force in agriculture, while more and more men are moving into non-agricultural production. ${ }^{7}$

The 'double study' component of the campaign involves courses in adult literacy education and in practical and technical skills. In the early years of the campaign, effort was directed primarily at recruiting illiterate and semi-illiterate women for very short-term classes in basic technical skills aimed at immediate income generation, combined with literacy education, but over time attention has shifted to more systematic improvement of the technical skills of already relatively well-educated women, who are more likely to use those skills to become entrepreneurs and then support and employ other rural women. The 'double compete' component of the campaign entails the promotion of women hailed as models because of their success in the market economy, combined with their willingness to share their success with other rural women and to provide financial help to women poorer than themselves. ${ }^{8}$

Since the 1990s, foreign donors and newly-established domestic NGOs have complemented the work of the ACWF by funding some projects aimed at improving rural girls' education and rural women's reproductive health, and at providing basic amenities such as accessible water and schools. Aside from this, however, most projects conducted by both domestic NGOs and overseas agencies have been similar to those of the ACWF in focusing on strengthening the ability of women to compete in the market economy. Most women and development activists in China-whether they work for the ACWF, domestic NGOs, or overseas agencies-believe that postMao market-oriented economic policies offer new opportunities for women, and that it is important to position women to maximize these opportunities and not be left

5. See Tamara Jacka, Women's Work in Rural China. Change and Continuity in an Era of Reform (Cambridge: Cambridge University Press, 1997), pp. 93-95.

6. The 'double study, double compete' campaign was initiated in some places in the mid-1980s and then formally announced at the national level in 1989. Initially it was planned to run for five years, but it was then made permanent. For details of the campaign see Jacka, Women's Work in Rural China, pp. 96-97; Ellen Judd, The Chinese Women's Movement. Between State and Market (Stanford, CA: Stanford University Press, 2002), pp. $33-54$.

7. Jacka, Women's Work in Rural China, p. 97.

8. Judd, The Chinese Women's Movement, pp. 52-54. 


\section{TAMARA JACKA}

behind in the race for development and modernity. ${ }^{9}$ Some have been critical of the negative consequences of particular post-Mao policies, but by and large they have not challenged the state's program for development and modernization, ${ }^{10}$ premised as it is on the notion that national development will come through industrialization, the building of a consumption-oriented market economy integrated into the capitalist world order, and the subsumption of concerns over social equity and environmental protection to the demands of rapid economic growth.

In the 1980s and 1990s members of both the ACWF and other Chinese women's organizations typically couched their aims in terms of 'raising women's quality' (tigao funü de suzhi). This was first declared to be the central goal of the ACWF at its Fifth National Women's Conference in 1983. Subsequently, in 1986, at a work conference to discuss aims and plans for women's work in rural areas during the subsequent five year period, leading officials of the ACWF emphasized that

Organizing and mobilizing women to take part in commodity production and helping women to speedily overcome poverty and get rich is the task bestowed on rural women's work in the new period. How must the Women's Federation grasp this task, what should the focus of our work be, and how will we achieve breakthroughs? The key lies in raising women's quality. ${ }^{11}$

These officials stressed that:

Raising women's quality entails, first of all, raising the quality of rural women's political thought [zhengzhi sixiang suzhi] ... It is necessary to educate women to liberate themselves from the fetters of traditional, small-scale production and egalitarianism, and to make the bold development of commodity production the focal point for the implementation of women's education in the 'four haves' [siyou: to have motivation, education, determination and aspirations] and the 'four selfs' [sizi: self-respect, selfconfidence, self-reliance, and self-strength] ... Secondly, [we must] expand technical training on a broad scale, at many levels and using many forms and avenues, so as to raise women's capabilities in developing commodity production. We must vigorously develop practical technical training, energetically nurture the different kinds of talents amongst women that are needed in rural areas, and make this a focus of raising women's quality. ${ }^{12}$

More than a decade later, at the First National Forum on the Protection of the Rights of Rural-to-Urban Migrant Women Workers (Shoujie Quanguo Dagongmei quanyi wenti yantaohui), organized by the Rural Women collective in 1999, rural women's 'quality' was again the focus of concern among delegates who included NGO activists and journalists, as well as grass roots Women's Federation representatives. Li Tao, organizer of the Migrant Women's Club run by the Rural Women collective, argued that rural women's 'low quality' was the chief cause of the

9. Ibid., pp. 19-32.

10. Wesoky, Chinese Feminism Faces Globalization, pp. 56-59.

11. Zhang Guoying, '1986 Nian Liu Yue Ershisan Ri zai Sheng, Shi, Zizhiqu Fulian Zhuren Gongzuo Huiyi shang de Zongjiehua' ['Concluding remarks to the Work Conference for Women's Federation Representatives at Provincial, Municipal and Autonomous Region Levels, 23 June 1986'], Funü Gongzuo [Women's Work], (August 1986), p. 9.

12. 'Xin Shiqi Nongcun Funü Gongzuo de Xin Renwu-Yi Jiu Ba Liu Nian Liu Yue Sheng, Shi, Zizhiqu Fulian Zhuren Gongzuo Huiyi Jiyao' ['The new tasks of rural women's work in the new period—a summary of the 1986 Work Conference for Women's Federation Representatives at Provincial, Municipal and Autonomous Region Levels'], Funü Gongzuo [Women's Work ], (August 986), pp. 3-4. 
social problems they faced in the city, including frequent violations of basic rights, difficulties in finding a marriage partner, a sense of inferiority and feelings of hopelessness about the future. In essence, he argued, their low quality meant that they were unable to manage the obstacles thrown up by a society in transition. Consequently, raising migrant women's quality was the most important means by which to address their problems. ${ }^{13}$

According to Li Tao, there were three aspects of rural migrant women's low quality that needed to be addressed. First, their 'psychological quality' (xinli suzhi) needed improving. Through group discussions, excursions and holiday celebrations put on by the Migrant Women's Club, he hoped that rural migrant women would come to feel like one big family and be able to speak freely and give each other encouragement, and thereby overcome their feelings of inferiority and loneliness. Through talks on issues relating to marriage and adapting to city life, they would overcome their bewilderment in the city and learn a greater degree of endurance and adaptability. Second, the quality of their thinking (sixiang suzhi) needed to be improved. He felt that by listening to the stories of rural women model achievers, migrant women's fighting spirit and creativity would be kindled and they would be inspired to adopt a sense of historic responsibility for building the urban economy and lifting their home counties out of poverty. Finally, Li Tao argued that the most urgent need was for rural migrant women's educational or cultural quality (wenhua suzhi) to be raised. In other words, they needed to improve their basic education and to develop technical skills. ${ }^{14}$

In post-Mao China, quality (suzhi) has become a key element in a range of discourses on development and the achievement of modernity and national power. It can and has been used to refer to a host of attributes, including education, culture, morality, political orientation, manners, psychology and physiology. The key to understanding its significance is not to pin it down with a precise definition. Rather, it is important to recognize, first of all, the real utility and power of the term's flexibility and the fact that it can be deployed in so many different discourses. For the women's movement, the multiplicity of meanings that can be attached to the terms 'quality' and 'raising quality' is potentially a double-edged sword. Tailoring the specific meanings of these terms for one's own purposes may be a valuable strategy for gaining state legitimacy and support for projects aimed at furthering women's interests that might otherwise be regarded as of marginal importance or as conflicting with the state's main development aims. All the same, the terms belong to and inevitably carry connotations of a broader discourse. This is problematic because there are some obvious ways in which the 'quality' discourse contributes to forms of governmentality and social differentiation that run counter to efforts to promote social equality.

The first significant feature of the 'quality' discourse is that it focuses concern on people and how to improve them, while diverting attention away from deficiencies

13. Li Tao, 'Lun "Dagongmei zhi Jia" de Renwu ji Qiantu' ['A discussion of the mission and prospects of the Migrant Women's Club'], in Shoujie Quanguo Dagongmei Quanyi Wenti Yantaohui, Lunwenji [The Collected Works of the First National Forum on the Rights of Migrant Women Workers] (Beijing: Rural Women Knowing All Magazine, 1999), pp. 75-76.

14. Ibid. Tamara Jacka, Rural Women in Urban China: Gender, Migration, and Social Change (Armonk, New York: M.E. Sharpe), p. 14. 
and inequities resulting from structures and institutions either created or endorsed by the state, and absolving the state of responsibility for addressing those inequities. To some extent, the ACWF has shown that it can get around this. In her book The Chinese Women's Movement Between State and Market (2002), Ellen Judd shows that while the ostensible aim of the ACWF's campaign for 'two studies, two competitions' is to stimulate women to improve their 'quality' what is important and innovative about the campaign has been the way the ACWF has used it to secure commitments from the state to provide rural women with much-needed resources, including capital, technical expertise and market information. ${ }^{15}$ However, importantly, the 'quality' discourse reduces the expectation of services from the state, and normalizes a situation in which women are disadvantaged in the acquisition of resources.

The second important feature of the 'quality' discourse is that it promotes competition and differentiation between those labeled 'low quality' and those deemed 'high quality'. And for all its flexibility, the 'high quality' that is referred to is inevitably an attribute or ability that will enable the individual to contribute directly to market-oriented economic growth. Other conceptions of what 'quality' might be or what it might be for are erased in this discourse. ${ }^{16}$

In the women's movement, a combined stress on the responsibilities of the individual, on the virtues of the market, and on the cultivation of qualities in individuals that will contribute directly to market development, has resulted in an inability to adequately address deeply entrenched aspects of women's subordination that have worsened since the introduction of market reforms. Thus, while the ACWF and other women's groups have made some effort to combat trafficking and violence against women, their efforts have been hampered by a failure to challenge the state's depiction of such problems as being merely 'feudal remnants' from a past order. In fact, these problems have been exacerbated by the contemporary state's naturalization of gender inequality as resulting from biological difference; its reprivatization of issues relating to sexuality and intra-household decision making and divisions of labor; its collusion with the commodification of women's bodies that has become so central to the promotion of capitalist consumerism; and its withdrawal generally from direct efforts to overcome social inequality. ${ }^{17}$

At an even more fundamental level, the rhetoric of 'raising women's quality' has legitimated and perpetuated a general blindness to the deep, institutionalized imbrication between gender and power in contemporary society. Discrimination, disadvantage, subordination and violence against women in rural China, far from being a matter of women's 'low quality', are underwritten by two key institutions, neither of which has been addressed to any significant extent by either the ACWF or NGOs. The first is patrilocal, exogamous marriage, the dominant pattern of marriage in the Chinese countryside. Time and again it has been shown that girls' education is curtailed because of the widespread assumption that women leave their natal family and village upon marriage, and therefore that spending resources on their education is

15. Judd, The Chinese Women's Movement, p. 48.

16. Ibid., p. 30.

17. Harriet Evans, Women and Sexuality in China. Dominant Discourses of Female Sexuality and Gender since 1949 (Cambridge: Polity Press, 1997). 
like 'watering someone else's garden'. And once married, women who have moved out of their home village into that of their husband are disadvantaged in business and in political participation, and have low status and are vulnerable to violence in the home because they lack social contacts in their husband's community. ${ }^{18}$ The practice of exogamous marriage also exacerbates discrimination against women in property rights, since villages often withdraw a woman's use-rights to property when she marries out, while her new village does not accord her the rights to a new portion of land. ${ }^{19}$

The second key institutional underpinning of women's subordination is the gender division of labor, whereby women are concentrated in the least desirable and most poorly remunerated areas of work. In the Chinese countryside, the concentration of women, especially older women, in agriculture and the greater involvement of rural men in industry and work away from the home village, both proceed from, and contribute to, women's lower status, and often compound the workload of women who take over responsibility for agriculture as well as domestic work and in some cases family businesses, when their husbands leave home to work in industry.

To return to the 'quality' discourse, the promotion of competition that is inherent in this discourse contributes to particular forms of governmentality and socio-economic differentiation. The idea that anyone and everyone can and should raise their 'quality' has been promoted in a wide range of post-Mao discourses. In fact, one could suggest that 'quality' itself is less central to post-Mao strivings for development and modernity than is the notion that a person's and a nation's 'quality' are not fixed, and that they can either fall behind others' or be raised. This feeds and answers to new, very powerful, desires and anxieties in the populace. The possibility of attaining higher levels of 'quality' for oneself, of competing with others over who has the most 'quality', of feeling superior because of one's 'quality' and looking down with either sympathy or contempt on those who have less, has proved enormously enticing. The engendering of these new desires and anxieties in turn has become at least as crucial to the market economy and to state governance as are the desires for material wealth and consumption. Thus, at the macro level, raising the population's 'quality', through, in particular, family planning, crackdowns on crime and disorder and the disciplining and training of the work force has been seen, both by the state and in the general populace, as crucial to national 'development', an all-important goal in China's competition with other nations for pride and power. And at the micro level, a desire for individual 'self-development' (ziwo fazhan), based on efforts to improve 'quality' through, for example, education, training in technical skills, and better diet and exercise, is not only promoted by the state as vital to national 'development', but has been internalized among ordinary people. Desires and anxieties over China's 'quality' as a nation thus fuse with competition over families' and individuals' personal 'quality', contributing to a powerful form of governmentality based on

18. Jacka, Women's Work in Rural China; David Goodman, 'Why women count: Chinese women and the leadership of reform', in Anne E. McLaren, ed., Chinese Women-Living and Working (London and New York: RoutledgeCurzon, 2004), pp. 19-41; Laurel Bossen, Chinese Women and Rural Development. Sixty Years of Change in Lu Village, Yunnan (Lanham, Boulder, New York and Oxford: Rowman and Littlefield, 2002), pp. $235-236$.

19. Yang Li and Xi Yinsheng, 'Women's rights to land under China's land contract system', paper presented at the Symposium on Women's Participation in Policy Implementation and Institutional Change in Rural China, The University of Nottingham, 14-16 April 2004. 
pressures toward self-regulation and self-development that are internalized amongst the people as much as they are imposed by the state from above.

Tapping into the enthusiasm for competing to raise one's quality and develop oneself, in particular by improving one's education and technical skills, might be construed as an effective approach toward increasing women's socio-economic capital and hence their status and position in the economy. However, Ellen Judd casts some doubt on this approach as it has been adopted by the ACWF in their 'double study, double compete' campaign. First, she shows that, in the village in which she conducted fieldwork, the women most in need of basic literacy education were among the poorest and most hardworking and the vast majority could not afford to devote time and effort toward taking classes. At the other end of the scale, not only were women in the minority of better educated villagers, but the women who did achieve relatively high levels of formal education and/or training were unable to translate that educational capital into improved employment or other forms of participation in the public sphere: in all cases, though they may have been employed in relatively high status work and/or been involved in politics before marriage, they lost that status and did not gain other wage employment after marriage and the shift to their husband's village. ${ }^{20}$

In general terms, and despite the state's claim that everyone can and should 'raise their quality', those groups marked out as having the lowest 'quality' have found that in practice this is commonly understood as a mark of innate inferiority that is allencompassing and extremely difficult to change. The attribution of 'low' or 'high' 'quality' coincides very closely with existing patterns of inequalities in power and socio-economic opportunity, including most importantly gender, ethnic, regional, and rural-urban inequalities. And far from being ameliorated, all of these inequalities are being exacerbated by market-oriented 'development'. Aside from gender inequalities, of particular concern here is that from the mid-1980s inequalities in income, education, health, welfare and security within rural areas and between rural and urban areas increased. By $1995 \mathrm{rural} / \mathrm{urban}$ income inequalities were greater than they had been at the beginning of the post-Mao period in $1978 .^{21}$ They were higher than any other form of inequality in China ${ }^{22}$ and also higher than rural-urban inequalities in any other country in the world except Zimbabwe and South Africa. ${ }^{23}$ This very high level of urban-rural income inequality was further responsible for the fact that by 1995 China had become one of the most unequal countries in Asia, with a Gini ratio estimated at 0.452 - higher than India, Pakistan and Indonesia, and similar to the Philippines. ${ }^{24}$ This should surely be of concern to a women's movement trying to improve the lives of all women, not just those of a minority of urban women.

Finally, the 'quality' discourse embodies a profoundly elitist attitude toward social change and development, for despite the notion that everyone can and should raise their 'quality', it is most commonly believed that those of 'low quality' - less

20. Judd, The Chinese Women's Movement, pp. 55-76.

21. John Knight and Lina Song, The Rural-Urban Divide. Economic Disparities and Interactions in China (Oxford: Oxford University Press, 1999), p. 319.

22. Azizur Khan and Carl Riskin, 'Income and inequality in China: composition, distribution and growth of household income, 1988 to 1995', China Quarterly no. 154, (1998), p. 246.

23. Knight and Song, The Rural-Urban Divide, p. 337.

24. Khan and Riskin, 'Income and inequality in China', p. 246. 
educated, rural, non-Han people, and especially women — cannot raise their own 'quality' by themselves, but require the guidance and help of 'high quality' peoplethat is, educated, urban, Han people, especially men. This kind of elitism has been a serious problem for the Chinese women's movement. In the case of the Migrant Women's Club run by the Rural Women collective, for example, the stated aims of overcoming feelings of inferiority and stimulating agency among rural migrant women were frequently stymied in sessions where urban 'experts', invited to the Club, lectured down at their migrant audience. In my interviews with members of the Club, some women expressed a deep-seated sense of inferiority with respect to educated urbanites. Others were highly resentful of the fact that urbanites were deemed of 'higher quality'. Both of these responses point to the forces working against the improvement of rural women's self-confidence and agency, and against the nurturing of creative alliances between rural and urban women. ${ }^{25}$

The elitism, and the focus on individual weaknesses rather than structural inequalities that is characteristic of 'quality' discourse have led a number of nonChinese feminists and development activists to criticize the Chinese women's movement's use of this discourse. As a result, since the late-1990s there has been a decline in usage of the language of 'quality' in both the ACWF and other groups, and some direct criticism of the 'quality' discourse from activists within these groups. ${ }^{26}$

Simultaneously, contact with overseas academics and development activists, and involvement in development projects funded by overseas agencies such as the Ford Foundation, have introduced women's activists in China to new terms and concepts, such as 'gender awareness' and '(self) empowerment', and to new approaches to development-including, in particular those espoused in the Gender and Development (GAD) model. The questions that must now be asked are: how different in fact is the 'raising quality' approach to women and development from approaches taken by overseas development agencies? At what points do these approaches diverge and converge? Does global development discourse offer approaches toward women and development that are different from that currently taken by the women's movement in China and, if so, do these approaches promise a more effective strategy for improving rural Chinese women's lives?

\section{WID, GAD, empowerment, and mainstreaming}

Three different approaches toward women and development are commonly identified in the development studies literature-Women in Development (WID), Women and Development (WAD), and Gender and Development (GAD). The WID approach was first advocated in the early 1970s by Western liberal feminists strongly influenced by

\footnotetext{
25. My discussion of the 'quality' discourse is developed further in Tamara Jacka, Rural Women in Urban China (Armonk, NY: M.E. Sharpe, 2005).

26. See, for example, Xie Lihua, 'Zhubian de Hua: Daodi Shei de Suzhi Di?' ['Editorial: whose quality is low?'], Nongjianü Baishitong [Rural Women Knowing All] no. 8, (August 1999), pp. 4-5; Gao Xiaoxian, 'Shehui Xingbie Fenxi' ['Gender Analysis'], in Xu Wu, Xu Ping, Bao Xiaolan and Gao Xiaoxian, eds, Shehuixingbie Fenxi: Pinkun yu Nongcun Fazhan [Gender Analysis: Poverty and Rural Development] (Chengdu: Sichuan Renmin Chubanshe, 2000), pp. 398-399; Du Jie, 'Gender and governance at the local level: women's participation in village elections in China', paper presented at the workshop on Gender, Socialism and Globalization in Contemporary Vietnam and China, Australian National University, 25-26 November 2003, p. 26.
} 
Ester Boserup's book, Women in Development (1970). In this book Boserup argued that women were missing out on the benefits of modernization. In order to redress this problem, women needed better access to education, technology and other resources, so as to improve their chances of competing with men for employment. ${ }^{27}$

WID theorists played a vital role in calling for the need for women to be integrated into development, and during the 1970s and 1980s their ideas were put into policy, if not always into practice, by almost all the major international development agencies. However, the WID approach has come in for strong criticism from feminists on the grounds that, for all its positive aspects, it remains within the framework of modernization theory and fails to challenge its most basic premises. In particular, the WID approach does not examine why women have fared less well than men from development strategies adopted since the 1970s, focusing only on how they can be integrated more fully into existing development programs. WID inspired projects tend to focus on the productive aspects of women's work, assuming that access to income-generating work will automatically improve women's lives, without giving serious enough consideration to existing gender divisions of labor, gendered differentials in control and access to both the inputs required for production and the products of labor, women's workloads and their reproductive work. It is also a rather ahistorical approach, tends to neglect the significance of class, race and culture on socio-economic relations, and does not recognize the existence of divisions and forms of exploitation that exist among women as well as between women and men. And finally, the WID approach does not recognize exploitation as a component of global capitalism, but simply as a local phenomenon that can be ameliorated through capitalist development. ${ }^{28}$ It tends to uphold a view, inherited from colonialism and deeply ingrained in Western approaches to development and modernization, of Third World women as a homogenous body of victims of Third World backwardness who can be lifted toward a higher level of development only by their superior and wellmeaning, expert Western sisters. ${ }^{29}$

The WAD and GAD approaches were developed in the second half of the 1970s and the 1980s, building on the insights of Marxist feminist scholars and activists and on the perceived deficiencies of the WID approach. WID and GAD have much in common, but the former is more oriented toward the macro picture-the global, structural determinants of the socio-economic position of women. While the WAD approach continues to play an important role in international policy and advocacy arenas, these days the GAD approach is of more immediate relevance to practitioners in the field of women and development.

The main international NGO associated with the GAD approach is DAWN (Development Alternatives with Women for a New Era), which was initiated at the Third World Conference on Women held in Nairobi in 1985, primarily by women from non-Western countries. As exemplified in the work of DAWN and some other

27. Caroline Moser, Gender Planning and Development. Theory, Practice and Training (London and New York: Routledge, 1993), p. 2; Eva Rathgeber, 'WID, WAD, GAD: trends in research and practice', The Journal of Developing Areas no. 24, (1990), p. 490.

28. Rathgeber, 'WID, WAD, GAD', p. 492.

29. Carolyn Cartier and Jessica Rothenberg-Aalami, 'Empowering the "victim"? Gender, development, and women in China', The Journal of Geography 98(6), (1999), p. 285. 
NGOs, GAD differs from the WID approach in focusing on women's reproductive as well as productive roles. GAD also puts greater emphasis on promoting the role of the state in maintaining and improving social services on which women and families depend, but which many states have recently reduced or privatized in the face of economic recession and/or economic 'reform' and structural adjustment. Another key focus of concern for GAD practitioners has been the strengthening of women's legal rights, especially in the areas of property ownership and inheritance. Above all, the GAD approach is less concerned with women per se, and more with the social construction of gender, and with the relationships between gender, class, race and development. And it puts more emphasis on the agency of women at the grass roots level and on encouraging women to build local alliances across potential social divides as a central element of improving the lives of all women. ${ }^{30}$

In recent years, GAD practitioners have emphasized two central concepts: '(self) empowerment', and 'gender mainstreaming'. In the 1980s the term 'empowerment' was taken up by GAD activists who argued that true community development required that local women (as well as men) be empowered to challenge and transform gender and other inequalities that shaped their lives and life-chances. For these activists, empowerment involved processes of consciousness-raising and the stimulation of collective mobilization among women. Through these processes, women would develop an awareness of inequalities and injustices that are otherwise normalized through dominant discourses and institutions, gain the confidence and ability to voice their interests and needs, and develop the collective capacities and forms of organization necessary to overturn inequalities and to further their interests and needs. ${ }^{31}$ Since the 1990 s, GAD advocates have also emphasized the need for 'gender mainstreaming'. In other words, they stress that rather than focusing on improving the situation of women only within women-specific projects, the transformation of gender relations must be put on the agenda of all development projects and beyond that, all mainstream social, economic and political institutions. All aspects of such institutions, including the drafting of legislation, and the determination of goals and priorities, staff appointments and the distribution of resources between and within institutions, must be assessed and transformed so that women and men will benefit equally. ${ }^{32}$

To a much greater extent than WID, the GAD approach, with its stress on empowerment and mainstreaming, calls for a thorough examination and transformation of fundamental social structures and institutions. Consequently, it is more threatening to existing elites, and harder to integrate into ongoing development strategies and programs. ${ }^{33}$ For this reason, this approach has been less popular among mainstream development agencies. Nevertheless, since the 1990s most development

\footnotetext{
30. Ibid., p. 286.

31. For further discussion, see Jane L. Parpart, Shirin M. Rai and Kathleen Staudt, 'Rethinking em(power)ment, gender and development: an introduction', in Jane L. Parpart, Shirin M. Rai and Kathleen Staudt, eds, Rethinking Empowerment. Gender and Development in a Global/Local World (London and New York: Routledge, 2002), p. 11; and Naila Kabeer, Reversed Realities. Gender Hierarchies in Development Thought (London and New York: Verso, 1994), pp. 223-263.

32. Suzette Mitchell, 'What lies at the heart of the failure of gender mainstreaming: the strategy or the implementation?', Development Bulletin no. 64, (March 2004), p. 8.

33. Rathgeber, 'WID, WAD, GAD', p. 495.
} 
agencies, including NGOs, government agencies and international bodies such as the World Bank, have espoused a commitment to GAD. ${ }^{34}$

Among feminist activists and development practitioners, however, there has been growing and widespread concern that the potential for GAD's empowerment and mainstreaming to improve gender equality and increase the benefits of development for women as well as men has not been realized in the practice of mainstream development agencies. Thus, contributors to the 2002 collection Rethinking Empowerment argue that empowerment has become a 'motherhood' term, easily agreed to because its meaning is vague, but that its deployment in the stated aims and policies of development agencies often masks strategies and behaviors that fail to promote, and in some cases even detract from, women's empowerment in practice.

In one paper in this collection, Jane Parpart undertakes a critique of Participatory Rural Appraisal (PRA), a methodology widely adopted by development practitioners to draw local people's knowledge into development projects, to empower those usually dismissed as marginal, voiceless and powerless, and to break down the usual hierarchy between development 'experts' and local recipients of aid. This methodology emphasizes group activities and techniques that do not require high levels of literacy, such as the collection of information through story telling, photography, map drawing and 'transect walks' in which local people walk with PRA facilitators around an area identifying local resources. ${ }^{35}$ Parpart notes that PRA has had many successes, but reports from the field indicate several problems and raise questions about some of the methods and assumptions of this approach, especially for women. ${ }^{36}$ In particular, Parpart argues, PRA and other approaches to participatory empowerment 'are under-theorized, especially in relation to power'. ${ }^{37}$ One of the main limitations of such approaches is that they do not take account of the fact that local power relations are embedded in, and affected by, discourses and institutions that are regional, national and international in scope. Even at the local level, power hierarchies are much more complex than PRA advocates generally acknowledge, and cannot be overcome merely through the encouragement of discussion and giving voice to the marginalized. In addition, most development practitioners come from cultures where women's subordination and need for direction is taken for granted, and even those who believe in participatory development methods find it difficult to give up their authority over poor, local women-wanting to empower them, but only on their terms. ${ }^{38}$

The other main problem Parpart identifies is that while participatory empowerment projects call for full local participation, they often underestimate the skills needed for such participation. Like all development projects, these projects must conform to demands for frequent written reports and budgets. Most rural people, especially women, lack the skills necessary to complete these tasks, so projects usually employ

\footnotetext{
34. Parpart et al., 'Rethinking em(power)ment, gender and development', p. 11; Beijing Declaration and Platform for Action, Fourth World Conference on Women, 15 September 1995. Available at: http://www1.umn.edu/ humanrts/instree/e5dplw.htm.

35. Jane Parpart, 'Rethinking participatory empowerment, gender and development: the PRA approach', in Parpart et al., eds, Rethinking Empowerment, p. 167.

36. Ibid., p. 169.

37. Ibid., p. 177.

38. Ibid., pp. 170-172.
} 
outside experts to handle them. Consequently, as Parpart argues, 'measurement and evaluations are once again the purview of the development "expert" rather than local people, and women, with their lack of skills, are left outside the loop'. ${ }^{39}$

Like the notion of empowerment, GAD's other core concept, 'mainstreaming', has also come under fire. Contributors to a recent issue of Development Bulletin devoted to gender and development argue that 'mainstreaming' has failed to improve gender equality in the way that was anticipated in the 1990s. ${ }^{40}$ A number of interrelated reasons are identified: the huge scope of work and expectations covered by the concept of gender mainstreaming, a lack of clarity and understanding surrounding the term, a lack of tools for analyzing, monitoring, and measuring outcomes of gender mainstreaming, a lack of resources and high-level commitment to the concept and the tendency for organizations, officials and development projects to make token commitments to gender mainstreaming without implementing measures that would in fact challenge or transform gender inequalities. As a number of contributors to the journal note, gender mainstreaming has usually taken the form of simply adding women's issues or gender issues to the mainstream agenda, rather than challenging or seeking to determine the mainstream agenda itself. In this it is similar to the 'add women and stir approach' - a phrase used to denigrate WID work in the early 1970s. Even worse, some contributors note that gender mainstreaming strategies can sideline or threaten women-specific projects, and that, in general, the focus on 'gender' and 'gender mainstreaming' threatens to dilute attention to women and their interests, rather than empower them. ${ }^{41}$

\section{From 'raising women's quality' to GAD}

Returning to the Chinese case, Ellen Judd claims that in China 'the official women's movement is attempting what is, in effect, a domestic Chinese variant of gender-anddevelopment'. ${ }^{42}$ This is misleading. Despite its 'quality' rhetoric-which to nonChinese ears sounds quite alien - the practice of the All China Women's Federation in rural China resembles that of many international development agencies. But, as has been suggested, while the majority of international development agencies now espouse the language of GAD, few really put its principles into practice. Like many development agencies across the world, the ACWF focuses primarily on incomegenerating schemes and on helping women to improve their skills and opportunities in a market economy. The ACWF's push for women to be better integrated in processes of market-oriented development, its acceptance of the existing gender division of labor and of patrilocal, exogamous marriage, and its failure to address gendered differentials in access to, and control over, property and the inputs and outputs of labor, bear all the hallmarks of the WID, rather than the GAD, model.

\footnotetext{
39. Ibid., p. 174.

40. Mitchell, 'What lies at the heart of the failure of gender mainstreaming', p. 8.

41. Ibid., pp. 8-9; Jenny Riley, 'Some reflections on gender mainstreaming and intersectionality', Development Bulletin no. 64, (March 2004), p. 83. See also, Ellen Judd, 'Afterword: opening spaces for transformative practice', in Marilyn Porter and Ellen Judd, eds, Feminists Doing Development. A Practical Critique (London and New York: Zed Books, 1999), p. 219.

42. Judd, The Chinese Women's Movement, p. 27.
} 
Judd does highlight one area of affinity between the ACWF's approach and the GAD model when she notes that the ACWF uses the 'double study, double compete' campaign to extract more services from the state. There are also some similarities between the GAD approach to empowerment and the ACWF's approach to 'raising women's quality' and, specifically, to cultivating the 'four selfs'. This is no coincidence-one of the precursors of Chinese women's activists' strategies for 'raising quality' and nurturing the 'four selfs' is the Maoist political study group, which has also been an inspiration for the second-wave Western feminist emphasis on consciousness-raising and empowerment. Both the projects aimed at 'raising women's quality' and those aimed at 'empowering' women put particular emphasis on cultivating women's awareness of their interests, and teaching them to voice those interests through small-scale collective discussions and activities.

Despite the 'four selfs' rhetoric, however, the ACWF's emphasis on rural women's 'backwardness' and the need to raise their 'quality' evinces a profoundly elitist attitude toward rural women that works against empowerment at the local level and that masks rather than challenges the institutions of inequality through which rural women's subordination is perpetuated. Gao Xiaoxian, Director of the Shaanxi Research Institute of Women's Studies, Marriage and the Family, and herself a member of the ACWF, argues this point:

[There are] deficiencies in the way in which the 'double study, double compete' campaign has been conceptualized. The theoretical assumption underlying the campaign is that rural women's lesser participation in rural modernization can be explained by their cultural and technical backwardness, and, therefore, that attempts to improve it should focus on literacy and technical training. This closely resembles the first stage in international approaches to women and development, that is 'Women in Development' (WID). But this approach has been criticized because it does not challenge the underlying reasons for this state of affairs [i.e. women's cultural and technical backwardness], and has been supplanted by the 'Women and Development' (WAD) and 'Gender and Development' (GAD) approaches. ${ }^{43}$

In the last few years, as I mentioned above, there has been some criticism of the 'quality' discourse in the Chinese women's movement. In addition, some researchers and activists, both inside and outside the ACWF, have begun to adopt the global language of GAD, empowerment and mainstreaming. Some have learned these terms and concepts through study in the West. Others have been introduced to them through translated texts, and yet others have been trained through development projects run by international development agencies. By now there is, in fact, a significant cohort of activists who have experience in, and are keen to promote, the GAD approach. $^{44}$

Despite an increasing involvement of its employees in GAD research, training, and practice, the national policies of the ACWF still show little sign of the new discourse,

43. Gao Xiaoxian, 'Funu yu Fazhan zai Zhongguo: Dui Shijian de Fenxi yu Zai Renshi' ['Women and development in China: a practice-based analysis and review'], in Xu Wu et al., eds, Shehuixingbie Fenxi, pp. 12-13.

44. These, mostly highly educated urban women, have come together to form the Gender and Development in China network, whose website, set up in 2000 with financial assistance from Oxfam Hong Kong, is aimed at promoting gender and development research and training, and providing a platform for the exchange of information amongst GAD researchers and workers. The website can be seen at http://china-gad.org. 
continuing instead to emphasize the need to 'raise women's quality' ${ }^{45}$ In contrast, most Chinese NGOs concerned with women and development now eschew the language of 'quality', and their policies and projects are strongly influenced by the GAD discourse. For example, in the promotional leaflet for the Cultural Development Center for Rural Women, published in 2001, the Center's goal is described as being:

[to] support Chinese women, especially poor women, [in their efforts] to improve their position with regards to production, living conditions, health and education, and through the provision of health, cultural, technical, legal and information services, promote gender awareness [shehui xingbie yishi], raise capabilities for community development [shequ fazhan] and realize self-empowerment [ziwo fuquan] and sustainable development [kechixu fazhan] for rural women. ${ }^{46}$

Reports of self-described GAD projects, implemented both by overseas agencies and by Chinese women's organizations, emphasize the participation and empowerment of local rural women. ${ }^{47}$ In the remainder of this paper I draw upon these reports, as well as the discussion above, to highlight both the potential benefits and the likely limitations and pitfalls of a shift from 'raising women's quality' to GAD in rural China.

I have argued that the 'raising women's quality' approach, like WID, reflects an elitist conception of development, and that it fails to challenge the institutions and structures that underpin gender inequality. Replacing the 'raising quality' language with an advocacy of grass roots participation and empowerment may be an important step toward shifting understandings of development for rural women, both among donors and activists - most of whom are educated, urban women - and among the current 'recipients' of development, who are primarily less educated, poor rural women. In practice, however, the outcomes of 'empowerment' are not so very different from 'raising quality', as it has been interpreted and practiced by Chinese women's activists.

First, as mentioned above, there are some similarities between empowerment and the cultivation of the 'four selfs' as part of 'raising women's quality'. It is, I believe, for this reason that Li Zhen, formerly a leading member of the Cultural Development Center for Rural Women, remarked in 2002 that 'raising quality' is part of 'self-empowerment'. The Center's shift in focus from 'raising quality' to

45. The ACWF constitution stipulates that the first two responsibilities of the ACWF are (1) 'To unite and mobilize women to throw themselves into reform and the construction of socialist modernization, and further economic development and social progress'; and (2) 'To educate and lead women to foster a spirit of self-respect, self-confidence, self-reliance and self-strength, raise their overall quality and further overall development'. With only minor changes in wording, these have remained constant since 1988. See the ACWF constitution at http://www. women.org.cn/zhuanti/9da/dhwj/zhangchengzongze.htm.

46. Cultural Development Center for Rural Women, Publicity leaflet, 2001, p. 2. Italics added.

47. See, for example, Yang Hui, 'Shehui Xingbie yu Fazhan de Shijian yu Sikao-Yichuan Ge'an de Jingyan yu Fansi' ['The practice of gender and development and thoughts about it—experience in Yichuan and reflections on it'], Xibu Nuxing [West Women ], (24 March 2003), available at: http://www.westwomen.org/chinese/dsj2.asp?id = 372; Fang Lian and Du Fangqin, 'Zai Nongcun Shehui Xingbie yu Fazhan Moshi zhong Changshi Funü FuquanMancheng Ge'an' ['Empowering rural women in a gender and development model: a case study in Mancheng County'], in Xu Wu et al., eds, Shehuixingbie Fenxi, pp. 207-218; Anne Bunning, 'A microcredit success story: women make the difference', Development Bulletin no. 64, (March 2004), pp. 63-66. The emphasis on participatory empowerment in the Ford Foundation Reproductive Health Program is discussed in Wesoky, Chinese Feminism Faces Globalization, pp. 205-211. 
'self-empowerment', as evident in its list of goals quoted earlier, was, Li Zhen claimed, simply a change in terminology rather than an indication of a change in direction. ${ }^{48}$

In practice, as suggested in relation to both the ACWF and the Migrant Women's Club, the elitism of efforts to 'raise women's quality' has often limited their effectiveness in developing the 'four selfs'. However, GAD approaches to empowerment may not necessarily be any less elitist. As Jane Parpart's critique of PRA suggests, even development projects that stress the participation and empowerment of local people are commonly managed by outsiders who come from cultures that accord a lesser status to poor people, especially women, and who therefore display elitist attitudes toward such people. In China, even in projects that employ only 'locals' this is likely to be of particular concern because among those most likely to be employed to run development projects - i.e. educated urbanites - the notion that rural women are inferior and need their assistance runs deep. In this regard, it is noteworthy that reports on Chinese NGO projects that take a GAD approach stress the significance of gender awareness classes and discussions for raising women's consciousness and overcoming their reluctance to speak in public, but say very little about the existing knowledge and capabilities of poor women, whether they are specific skills, knowledge about the local community or its cultural traditions, or the considerable capabilities that women exercise in order to manage double and triple work burdens and to make ends meet in poverty-stricken conditions.

From a different perspective, Parpart's critique of PRA also suggests that the potential for Chinese GAD projects to 'empower' rural women to take charge of development in their community may be limited by the fact that they do not possess the particular skills of literacy and numeracy necessary for fulfilling the reporting and other requirements routinely demanded by development agencies. Xie Lihua, head of the Rural Women collective, notes that the difficulty of involving rural women in the management of development projects is compounded by the fact that the majority of rural women are psychologically low in 'quality' in the sense that they are reluctant to speak in public, let alone take charge of matters in the public sphere. Xie argues against the popular notion that this lack of 'quality' in rural women is a biological given. Rather, she suggests, 'quality' is something acquired through social praxis. ${ }^{49}$ Xie's retention of the term 'quality' remains problematic, but her argument nevertheless draws attention to an important issue-namely, that rural Chinese women's full participation in development projects entails not just the acquisition of technical skills, but also a major shift in cultural and psychological orientations. The difficulty of achieving such a shift and the resistance it is likely to meet should not be underestimated, for there is a long history of ostracism, abuse and violence against women in rural China who participate in public discussions and activities. ${ }^{50}$

Beyond this, reports of GAD projects in rural China indicate that when women do participate in collective discussions and activities their voices are often ignored, and sometimes these activities are thwarted by local power holders. For example, a report

48. Personal communication, December 2002. See also, Jacka, Rural Women in Urban China, pp. 66-67.

49. Xie, 'Zhubian de Hua', p. 5.

50. For an example of a rural man's violent resistance to his wife's participation in collective discussions in a GAD project, see Yang Hui, 'Shehui Xingbie yu Fazhan de Shijian yu Sikao'. 
of one GAD project that implemented PRA indicates that during the four years of the project, the needs voiced by village women were repeatedly rejected as unimportant, not just by male villagers, but also by local officials, including the Women's Federation representative. Collective discussions were also manipulated by officials. Thus, on one occasion three years into the project, villagers voiced the desire for a health center to be built. However, they offered only vague and conflicting reasons as to why the center was important, and when asked to choose between several funding priorities, they put the health center at the bottom of the list. It emerged later that the County Health Department had put pressure on villagers to ask for the health center. ${ }^{51}$

However challenging to local elites it might be to enable rural women to speak for themselves in public and be listened to, the extent to which this can transform other aspects of gender relations may be limited. In China to date, the most successful GAD projects have empowered local women to call for the fulfillment of practical needs, such as improved access to water and health education, as well as income generation. However, reports give no sign that these projects have challenged the ways in which women's disadvantage and lack of power are perpetuated through patrilocal, exogamous marriage and the gender division of labor.

It is perhaps unrealistic to expect individual development projects on their own to overcome or challenge deeply entrenched hierarchies of power. To achieve this goal, GAD projects aimed at empowering women in particular rural communities must be supported through broader-level efforts to challenge institutions that are central to rural women's subordination. Given that it is a national, semi-state body, one might expect the ACWF to play a key role in such efforts. The reason that it has not yet done so may be that it has neither the resources nor the political clout. Certainly, at the county level and below, the ability of Women's Federations to act at all is limited by the fact that they have very few staff and they are answerable to local government and dependent upon it for funding. ${ }^{52}$ At the national level, however, the ACWF has recently had some success in lobbying the state to address gender issues. For example, it was largely responsible for the introduction of the Women's Rights Protection Law in 1992. The 1995 Fourth World Conference on Women further spurred the Chinese state to make other important commitments to furthering gender equality. These are set out in the Program for the Development of Chinese Women of 1995-2000 and 2001-2010. In addition, the Conference gave added legitimacy to ACWF efforts to ensure that gender concerns are addressed in mainstream policy making. ${ }^{53}$

It may be that the legitimization of 'gender mainstreaming' will make it easier for the ACWF to implement concrete measures to address gender inequality in rural areas, including measures that challenge patrilocal, exogamous marriage and the gender division of labor. It may also help gender inequality to be seen as a concern that must be addressed by all state bodies, rather than as just a 'women's problem' that need not be addressed by mainstream state departments because it is the responsibility of the ACWF. Recent feminist critiques warn us, however, of the

51. Ibid.

52. For details, see Jacka, Women's Work in Rural China, p. 92.

53. See The Role of Chinese Women in Gender Mainstreaming, available at: http://www.womenofchina.com.cn/ magazines/2004/200403/role.htm, accessed March 2004. 
possibility that a professed commitment to 'gender mainstreaming' on the part of state bodies might further weaken the authority of the ACWF and its women-specific approach, while not posing any serious challenge to gender inequalities in practice.

\section{Conclusion}

Since the late-1990s, increased contact with overseas activists and academics, combined with pressure from global development agencies, has led women's groups in China to change their approach to women and rural development. Previously, members of both the ACWF and Chinese women's NGOs commonly couched their aims and strategies in terms of the state's discourse of 'raising (women's) quality', but today, many are highly critical of such rhetoric. In rural areas the ACWF continues to focus its efforts toward 'raising rural women's quality' through the 'double study, double compete' campaign, but the dominance of this campaign is increasingly being challenged by 'gender and development' (GAD) projects financed by global development agencies and run in conjunction with Chinese women's NGOs and/or local representatives of the ACWF.

I have argued in this paper that in theory, GAD promises to address major shortcomings in the 'raising women's quality' approach to women and development, including, most importantly, a high level of elitism, and a tendency to 'blame the victim' rather than to address the structural underpinnings of rural women's disadvantage. However, the practice of GAD has failed to overcome these limitations. In rural China, as elsewhere, GAD projects emphasize the need for the participation and empowerment of local rural women. Their success in achieving these goals, is, however, seriously limited by the fact that, like projects aimed at 'raising women's quality', they fail to acknowledge, much less contest, the key institutions that underpin women's disadvantage and lack of power-patrilocal, exogamous marriage and the gendered division of labor.

Since 1995, the ACWF and the Chinese state have embraced the rhetoric of 'gender mainstreaming'. It is to be hoped that in years to come they will act on this rhetoric, and work toward overcoming the inequitable consequences of patrilocal exogamous marriage and the gender division of labor in rural areas, thus providing an environment in which rural women nationally can participate equally in, and enjoy the benefits of, individual development projects. However, there is no sign of this occurring in the near future. 